\title{
Situational Approach in the Social-Human Cognition: Objectives, Principles and Categories
}

\author{
Pavel V. Veklenko* \\ Omsk Academy of the Ministry of Internal Affairs of Russia \\ 7 Komarova, Omsk, 644092, Russia
}

Received 06.08.2014, received in revised form 16.10.2014, accepted 21.12.2014

\begin{abstract}
The article gives a general description of the situational approach to solving problems of the socialhuman cognition. The author considers the removal of contradictions between the objectivist (natural science) and the subjectivist (the humanities) methodological orientations in the social-human cognition as the objective of the situational approach. An overview of the theoretical foundations of the situational approach - the introspective ontology going back to Kant's theory of cognition and theory of situations based on the non-classical tradition of philosophizing - is given. The article discusses the conceptual apparatus of the theory of situations, categories that describe the statics of the situation as a subjective-objective structure and the dynamics of the situation as the rationalconditional interaction and relation between the situations.
\end{abstract}

Keywords: situation, situational approach, social-human cognition, introspective ontology, theory of situations.

Research area: philosophy.

The situational approach in the cognition (situational research programme) is a concept of the methodology and philosophy reflecting a specific view of reality and ways of its rational development based on the theory of situations and defining the development of situational methodology. It can be compared to the cybernetic, system, information, synergetic and other interdisciplinary approaches that define a specific view of the world. Unlike the intuitive situational orientation typical for many modern scholars, the situational approach proposed by the author of this article is based on the theory of situations, and not on "situational representations", which have not been subjected to philosophical and methodological reflection. The theory of situations, in turn, is based on the principles of the introspective ontology formed in the framework of the non-classical philosophical discourse. In order to clarify this point of view, let us have a closer look at the sequence "introspective ontology - theory of situations - situational approach".

The roots of the introspective ontology go back to Kant's philosophy. The philosophy of the great German philosopher introduces the concept of an epistemologism (Lektorsky, Shvyrev, 1983, pp. 19-23), according to which it is not the being that generates the subject, but the subject creates the being (the only phenomenal being available

(C) Siberian Federal University. All rights reserved

* Corresponding author E-mail address: mvdfilosof@yandex.ru 
for experience opposed to the "thing in itself") Kant's epistemologism is the "non-classical impetus", which will subsequently cause a rapid development of phenomenology, existential philosophy and postmodern tradition with its value relativism and lead to the formation of the introspective ontology as a covert programme of non-classical philosophizing. The introspective ontology is characterized by:

1. The antecedence of the subject in relation to the being (the epistemologism opposed to the ontologism of the classics);

2. Understanding of the individual subject as the utmost basis of the being (as a counter to the abstract-general subject of the classics);

3. Interpretation of the being as the clash of the world (objective conditions) and the individual subject;

4. Consistent dualism - not narrowing it to "Me to the world" and vice versa;

5. Psychologysm - the subject sees the world in the introspective ontology only through the prism of the meaning projected by the subject.

These ontological principles form the theoretical understanding of the situation as a category that describes the anthroposocial reality along with such traditional constructs as "system", "fact", "individual" or "process". Thus, the situation is seen as a conditionalmeaning cooperation, which opens opportunities for removing the contradictions between subjectivism and objectivism in the cognition of man and society.

The concept of the modern social-human cognition is determined by two methodological principles: the first lies in the cognition of individual and social existence like the impartial and objective cognition of the natural being; this leading origin is most consistently embodied in various forms of positivism; the second, vice versa, reflects a desire for full disclosure of the subjective determinants of social and individual existence - this principle is implemented in different kinds of "reading" of anthroposocial reality presented in the existential literature, hermeneutical practices and postmodern speculations. There is no doubt that methodological programmes based on the ideas of "the priority of objectivity" and "the priority of subjectivity" are fruitful. However, in the first case, psychological and personal factors are rejected and the empirical material is forced into a certain scheme called "the law of social development" similar to "the law of nature". In the second case, the researcher is facing another serious threat - a break with the objective reality and falling into bad infinity of interpretations, reading "between the lines", digging in a heap of meanings, allusions and unspoken words. Naturally, the question arises - can there be an instrumental, methodological synthesis providing complementarity of these two principles and, correspondingly, overcoming the extremes of objectivism-subjectivism? We can state the problem otherwise: is the choice of a social-human researcher limited by the roles of an "impartial observer" or a "free artist"? Is a compromise possible between the methodological orientations of the natural sciences and the humanities that generated the ideological contradictions?

The "situation" category as a result of the synthesis of the objectivist constructs "system", "structure" and the subjectivist "meaning" is supposed to act as a theoretical and methodological mediator allowing the "free artist" to enter into a dialogue with the "impartial observer". The conceptual means that can be divided into three groups provide the productivity of the dialogue. The first group describes the situation in its static aspect as a structure, the second one represents the dynamic aspect of the situation as a conditional-meaning cooperation, and the third fixes the link between different situations. The 
first group includes the concept of the "subject", "circumstances" and "sense", the second includes the "purposefully rational kernel of the meaning", "peripheral contents", the "stimulating dominant", the "suppressing dominant"; and the third one contains the "super productivity of the situation", the "metasituation", the "event component of the situation", the "semantic component of the situation" and the "effect of the situation".

Let us consider these categories in more detail. It is unlikely to avoid some triviality during the analysis of the structure "subjectcircumstances-meaning": the subject is only possible in the circumstances. However, this is not enough to overcome the ordinary, although true, definition of the situation as the unity of the subject and circumstances. The ordinary language implies that there is meaning between them, but it does not give a clear picture. Even at the initial, vital practical level of philosophizing one should not claim otherwise - if the subject is not able to comprehend what is happening, if his/her consciousness is idle, the very statement about the presence of the subject as it is reflected by the established definitions of philosophy is meaningless: "In relation to physical things and cultural objects, the subject acts as a source of cognition and transformation. The subject exists only in unity of I, interpersonal (intersubjective) relationships and cognitive activity and the real activity" (Lektorsky 2001, p. 155). Accordingly, understanding of the circumstances is the attribute of the situation. The situation is always the result of reflection - in these projections of meanings on what is happening and reflections of what is happening by the consciousness there is the difference of the "situation" from the "objective conditions of life" or "position "- in the existential tradition. The condition becomes a situation when it delivers typical difficulties that require overcoming from a man, which are known as a restriction in the course of overcoming them, thereby the increased human activity is simultaneously awakened (Bol'nov, 1999, p. 54). Thus, the situation is not being in the objective conditions, the situation is an organic unity, the event of the subject and the world, as it is revealed in the experience. The subject is experiencing a clash with the world, and to experience means to feel all the emotions to the full - from fear and hatred to admiration and love. The interpenetration of the world and the subject with the need causes the meaning of life.

Therefore, the subject is a generator of meanings mediating the activity. "Mediation" between the man and the reality that he cognizes and transforms is not a new subject in philosophy. It is stated quite clearly in the "Essays" of Montaigne already. In the Chapter titled "The fact that our perception of good and evil, to a large extent depends on the view that we have", Montaigne gives a compelling example of subjectivity in the evaluation of the events of individual life: "We look at death, misery and suffering as our worst enemies. But everybody knows that the same death, which some consider to be the most terrible of all terrible things, for others is the only refuge from the troubles of this life, the supreme good, the source of our freedom, the full and final liberation from all sufferings?” (Montaigne, 1991, p. 41). The category "subject" covers various properties of the human being - the rational and the irrational, the spiritual and the physical, the ignoble and the sublime, the animal and the social. Anyway, this variety determines thoughts and actions, and therefore, the development and the outcome of the situation.

If in accordance with the philosophical tradition, the subject as a whole is interpreted as a source of cognitive, value-estimation and transformative activity mediated by the perfect, then the concepts of circumstances and meanings require further clarification. The circumstances are understood as external (in relation to the 
subject) conditions that determine his/her activity. The idea of the nature of the external circumstances can be specified as follows:

- in spatial relation as a perceived unavailability for the subject;

- in temporal relation as a precedence to the action of the subject;

- in functional relation as an independence from the subject during the moment of the action (Psikhologiia, 1990, p.364).

To clarify the concept of the circumstances by means of simple citation, and such method is quite effective, the circumstances may be represented by various natural, social and existential phenomena: eclipses of the sun, seasonal fashion and loyalty of colleagues, snowfalls, traffic jams and indifference of neighbours. The objectively defined parameters of the subject - the specifics of his/her bodily organization, intelligence, aesthetic preferences, temperament, etc. - should be added to these phenomena. It is obvious that the ongoing border between the "external" and the "internal" is artificial and is not always clear: "Something that ontologically belongs to consciousness, can be logically considered as the objective. The objective and the subjective in ontological terms cease to be rigidly opposed to each other, their ontological relativity is revealed" (Knigin, 2002, p. 35).

The circumstances in which the subject "exists" are capable of activating a set of values in the mind as the external stimuli - if the environmental empirical conditions respond, the values transfer into the state of "waking", become emotional and fill the mind. "Existence" (with an emphasis on indifference) transfers into the "event", the external circumstances are comprehended and become a situation with a relatively stable interpretation. Thus, the meaning is a complex of contents filling (forming) the consciousness of the subject under the influence of external factors.
Contents that form the meaning, i.e. sensual images and fragments of the folded inner speech are characterized not only by their high quality, negative, positive, or neutral emotional colouring, but also by their quantity - the degree of control on the part of the consciousness. Herewith, it is appropriate to use the arguments of the modern theory of the consciousness as a theoretical base, in the part that points at its heterogeneity: "One can talk about the center and the periphery of the field of the consciousness. It is only the center of the field that draws attention. But what is at the periphery, is also recognized, even though vaguely. We can argue about different degrees of the consciousness. Sleeping people are unaware of what is happening around, but there is a certain degree of consciousness during dreaming" (Lektorsky 2001, P. 165). As A.G. Spirkin notes: "at the given moment, when a man is deep in thoughts, he does not keep the focus of his mind on many things affecting him. Events and sounds that we see and hear, moving down the street, orient us in the flow of the traffic, although we do not focus on them; more precisely, our attention is as gliding on them and stops at something only in case of some difficulties and queernesses" (Spirkin, 1972, P.98).

Meaning as a subjective reality (Gusev, 2004, pp. 15-39) is a changeable structure ("being if nonidentical to itself" - M.M. Bakhtin), therefore, we can talk only about a relatively stable, purposefully rational kernel of meaning. Such a kernel is represented by sufficiently clear values that the subject projects on the outside world and himself/herself during his/her activities. These values are objectified to answer the question of the objective of the activities, i.e. the goal pursued by the subject and valuable justification of this goal. Herewith, the conceptual apparatus of the psychological theory of activities (Leont'ev) can be implemented to highlight the elements that form the purposefully rational kernel, namely: 
- the motif of the activities or conscious need provoking to perform this or that sequence of actions;

- the goal in its intentional aspect, as the image of the expected result of the activity;

- the goal in its operational aspect, as a method to obtain the targeted result.

However, the meaning is not exhausted by these values, its purposefully rational kernel is influenced by many other not so distinct sensual images and fragments of the folded inner speech. As the examples of these vague, peripheral contents erupting from the unconscious, we can list quite a wide range of phenomena of human existence accompanying human activities - fear, hope, doubt, remorse, belief that you are right, despair, guilt, depression, loneliness, anxiety, etc. To ignore these phenomena means to reduce the activity to reaching the goal and thereby to abandon the study of creativity in human activity aimed at the development of the surrounding reality, to reduce the human to an impassible robot.

The purposefully rational kernel of the meaning is not only permeable for indistinct, but emotionally charged values. It can be destroyed by the "breaking" peripheral irrational contents, which are defined as follows:

- contents related to the field of the unconscious reflecting the instinctive reactions of the body and provoking, for example, fear of death, or panic;

- contents related to the field of the unconscious, influence of nature or society uncontrolled by the consciousness, as well as actions that cannot be controlled by the consciousness's carrier (subsensorial perception);

- contents related to the field of the superconscious, non-personified requirements of the society and culture that provoke, for example, remorse, or, on the contrary, self-confidence.

In this context, scientific understanding of various psychic phenomena can be considered as an example. In modern psychology, there is a detailed description of the phenomenon of "the log over the abyss": "It is known that even though anyone with undisturbed vestibular function can safely walk the log lying on the ground, very few people can to repeat this action, if the same log is positioned at a height of several meters above the ground. Even if a person tries to do it, the probability of falling increases significantly" (Shcherbatykh, 2003, P. 80). This is due to the intervention of irrational factors - the selfpreservation instinct impels the consciousness to "play" a variety of causes that lead to the loss of balance and falling. The longer this situation is "played" in the head, the more likely it seems to the individual... after such psychological training a person would either refuse to perform such a "risky" trick or will fail forgetting how easily he walked the same log, when it was located on the ground (Shcherbatykh, 2003, P. 81). This example demonstrates quite clearly the destruction of motivation, complication and blocking of activities under the pressure of the peripheral, in relation to the centre of the consciousness, contents.

The next step is the clarification of the concepts of the "stimulating dominant" and the "suppressing dominant". These concepts reflect the level of organization of the peripheral contents sufficient to have a significant effect on the purposefully rational kernel of the meaning. Obviously, a variety of contents can penetrate in the sphere of the consciousness from the depths of the unconscious: structurally-stimulating, destructively-suppressing or indifferent relating to the current target of the subject in the situation. The concept of the "stimulating dominant" reflects the dominance of the breaking through contents 
of the constructive images and fragments of the folded inner speech stimulating the activities. The concept of the "suppressing dominant" reflects the opposite trend - the superiority of destructively-suppressing contents.

The constructs of the "stimulating dominant" and the "suppressing dominant" are necessary to clarify the phenomenon of the meaningful transformation of the reality revealing in situations under the influence of the dominants of the consciousness: the meaningful component of the situation (the meaning dominant) eliminates the effect of the event component of the situation (coincidence of objective external circumstances that generate it) and becomes the leading factor. In other words, the meaning, as the result of the interaction of values (purposefully rational kernel, stimulating and suppressing contents) composing the consciousness of the subject at the moment, defines the objective condition by means of activities, transforming unfavourable to favourable and vice versa. As noted in the psychological literature: "The human psyche is unique due to the ability to distract from the reality and take the actualized image (symbol, idea, belief) as a guide. And we can certainly state that the power of the psyche at this moment becomes equal to the power and greatness of the image that captured it" (Grimak, 1989, P. 110).

The construct "metasituation" indicates on the existence in a unique situation that emerged into a cultural universal. The metasituation is used to describe the mechanism of reproduction of the meaning of some "original, primary situation" recorded by the culture in countless numbers of similar "derivatives, secondary situations", which allows to establish links between the situations as relatively isolated fragments of the human existence, to present the human existence not as a mechanical joint of coincidences, but as an integrity, which implies some integrative effects and conflicting internal interaction.
The last concept, which describes the connection between the situations is "the effect of the situation". Its essence lies in the fact that the objective circumstances can restrict (block) the functions of the consciousness, actualizing the deeper, from an evolutionary point of view, archaic layers of the psyche. The impact of the situation on the human consciousness can lead to turning of the horizon of personal being to "here and now" with the total loss of "yesterday" and "tomorrow", the "past" and the "future", the "causes and effects", put the flexible adaptive system of rational control over the behaviour to the level of the hard circuits "stimulus-response".

The regression of the psyche under the influence of specific circumstances can be considered not only in phylogenetic perspective, as a return to the archaic, primitive models of behaviour typical for the biological mind in general, but also in terms of ontogenesis the individual development. The power of the situation over the mind can be found in the infantile responses to what is happening, as well as in clichéd actions prescribed by stereotypes. Both indicate the transition to the stages of the psyche development that are prior to the mature, creative and responsible attitude to the reality. The infantile response of an adult being at the mercy of circumstances, can manifest itself in activities, which are inappropriate for his/her and are more typical for children - persistent lies in the conditions of its futility, unexpected shyness, or, on the contrary, lack of restraint, naive imagination, etc.

Clichéd actions are a reproduction of another person's behaviour in a similar situation: the behaviour of parents, friends, main characters of fiction and films. The metasituation forms and provides the stereotype that in case of lack of time or lack of creativity allows to act in accordance with the model, without trying to understand the situation and develop one's own original solutions. 
Clichéd actions save effort on the part of the mind, but turns a man into a copycat, a copy, and sometimes a caricature. On the other hand, there is nothing wrong in imitating true heroes, if it is combined with the work of the mind and the development of one's own creative nature.

Therefore, "the effect of the situation" is characterized by varying degrees of intensity (further as descending): activation of the innate mechanisms of behaviour (instincts) or complete blocking of the rational component of the consciousness - an infantile reaction or partial blocking of the consciousness (critical thinking, self-control) - stereotyped response or a clichéd action.

Considering "the effect of the situation" as a regression of the psyche to the archaic, infantile or clichéd forms it should be noted that, firstly, the regression should not be evaluated purely negative - in a rapidly developing dangerous situation instincts can save live and health, infantile reactions in stressful situations act as a compensating mechanism (Fadiman, Frager) and clichéd actions can implement sublime ideas and facilitate the selection of an action in situations of indeterminacy.

Thus, the theory of situations examines the situation in the statics as a unity of subjective and objective factors, in the dynamics as a conditional-meaningful interaction, in a variety or some sequences as something that can broadcast its own structure within the cultural space. Therefore, the implementation of the situational approach in the consciousness is the use of theoretical constructs in the research practice as a descriptive-explanatory and heuristic means.

\section{References}

1. Bol'nov O.F. Filosofia ekzistentsializma [Philosophy of Existentialism]. Moscow, 1999. P. 54.

2. Grimak L.P. Rezervy cheolovecheskoi psikhiki [Reserves of the Human Psyche]. Moscow, 1989. P. 110.

3. Gusev S.S. Kommunikativnaiia priroda sub'ektivnoi real'nosti [The Communicative Nature of the Subjective Reality] // Epistemologiia i filosofiia nauki [Epistemology and Philosophy of Science]. 2004. №. 2, pp. 15-39.

4. Fadiman J., Frager R. Zashchitnye mekhanizmy [Defense Mechanisms] // available at: http:// psychology-online.net/articles/doc-1801.html

5. Knigin A.N. Uchenie o kategoriiakh [Study of Categories]. Tomsk, 2002. P. 35.

6. Lektorsky V.A., Shvyrev V.S. Edinstvo mirovozzrencheskogo i teoretiko-poznavatel'nogo aspektov v marksistskoi filosofi [The Unity of Ideological and Epistemological Aspects of the Marxist Philosophy]// Gnoseologiia v sisteme filosofskogo mirovozzreniia [Epistemology in the System of Philosophical Worldview]. Moscow, 1983, pp. 19-23.

7. Lektorsky V.A. Epistemologiia klassicheskaiia i neklassicheskaia [Classic and Non-Classic Epistemology]. Moscow, 2001, pp. 155, 165.

8. Leont'ev A.N. Deiatel'nost', poznanie, lichnost' [Activity, Cognition and Personality] [e-source] / A.N. Leont'ev - available at: http://lib.ru/PSIHO/ LEONTIEV/dsl.txt

9. Montaigne M. Opyty. Izbrannye glavy [Essays. Selected Chapters]. Moscow, 1991. P. 41.

10. Psikhologiia. Slovar' [Psychology. Dictionary]. Moscow, 1990. P. 364.

11. Spirkin A.G. Soznanie i samosoznanie [Consciousness and Self- consciousness]. Moscow, 1972. - P. 98. 
12. Shcherbatykh Iu.V. Psikhologiia strakha [Psychology of Fear]. Moscow, 2003, pp. 80, 81.

\section{Ситуационный подход \\ в социально-гуманитарном познании:}

задачи, принципы, категории

П.В. Векленко

Омская академия МВД России

Россия, 644092, Омск, пр. Комарова, 7

В статье представлена общзая характеристика ситуационного подхода $к$ решению проблем социильно-гуманитарного познания. В качестве задачи ситуационного подхода рассматривается снятие противоречия между объективистской (естественно-научной) и субъективистской (гуманитарной) методологическими ориентациями в социальногуманитарном познании. Осуществляется краткий обзор теоретических оснований ситуачионного подхода - интроспективной онтологии, восходящей к теории познания И. Канта и теории ситуащий, опирающейся на неклассическую традицию философствования. Рассматривается понятийный аппарат теории ситуаций, категории, описывающие статику ситуации как структурь субъективно-объективной природы, динамику ситуации как кондиционально-смыслового взаимодействия, а также связи между ситуациями.

Ключевые слова: ситуация, ситуационный подход, социально-гуманитарное познание, интроспективная онтология, теория ситуаџий.

Специиальность: 09.00.00 - философские науки. 